\title{
Internationalisation of Firms from Central and Eastern Europe:
}

\section{A Systematic Literature Review}

Peer-reviewed version forthcoming in European Business Review

\author{
Andrea Caputo \\ Lincoln Business School \\ University of Lincoln \\ Lincoln, United Kingdom \\ Massimiliano M. Pellegrini \\ University of West London \\ London, United Kingdom \\ Marina Dabic \\ University of Zagreb \\ Zagreb, Croatia \\ and \\ Nottingham Trent University \\ Nottingham, United Kingdom \\ Léo-Paul Dana \\ Montpellier Business School \\ Montpellier, France \\ and \\ Princeton University \\ Princeton, United States
}

\begin{abstract}
Purpose: The objective of this article is to provide a systematic review of the literature addressing internationalisation of firms from Central and Eastern Europe (CEE).

Design/methodology/approach: This article presents an inter-disciplinary systematic review of literature about the internationalisation of firms from CEE.

Findings: Three different clusters of research were identified. In the "Internationalisation Processes" cluster, containing many comparative studies, the focus is on specific approaches adopted by local firms in the process of internationalisation. One of the leitmotivs is the dichotomy between hostile home-country factors that create the need for internationalisation and market-seeking motives that guide the search for international expansion. The "Internationalisation Variables" cluster aims to explain the reasons of success or failure of internationalisation processes and strategies; this cluster focuses on possible facilitating or hindering aspects experienced by CEE firms and one often-cited element is the firm's network. Finally, the "Internationalisation Outcomes" cluster assumes a reverse approach when compared to the other two clusters. Indeed, the internationalisation phenomenon can also be studied in terms of its effect on the firm; the elements sought in these types of studies are both potential benefits and risks associated with internationalisation in CEE countries. The latter category in particular gives rise to interesting questions for future research.
\end{abstract}


Originality/value: Given that large, developed economies tend to receive much academic interest, and that smaller transitional economies are not always adequately represented in the scientific discussion, this article contributes to the literature on internationalisation.

Keywords: internationalisation, strategy, Central and Eastern Europe, CEE, exports, FDI, networks, literature review.

\section{Introduction}

The literature on internationalisation models of firms can be divided into two main streams of research: (i) stage models presented by the Uppsala model (Johanson \& Vahlne, 1977; Welch and Luostarinen 1988; Johanson \& Wiedersheim-Paul, 1975), and (ii) rapid internationalisation models, including the born global model (Oviatt and McDougall, 1994), and the early internationalisation model (Madsen and Servais, 1997). The first stream argues that firms pursue internationalisation in a slow and incremental fashion, which may be due to lack of knowledge about foreign markets, risk aversion, perceived uncertainty, and/or similar factors. The latter argues that many firms do not follow an incremental stage approach; rather they start their international activities from an early stage of life, which is possible as a result of advances in technology and liberalisation of government policy (Wright and Dana, 2003).

Both streams have been well documented and find much support in contemporary business practices, especially in the West. However, the internationalisation of firms from CEE countries appears to be relatively under-researched, even when compared to other transitional or emerging economies. CEE countries appear to underperform when compared to leading economies (World Economic Forum, 2014). Weak institutional support, insufficient innovation capacity and a long tradition of planned economy are seen to be among the main reasons for the gap separating CEE countries from the leading economies. Nevertheless, many CEE firms achieve strategic success and good performance on both domestic and international markets (Mair and Schoen, 2007). Further examples indicate that CEE firms still lag behind their western counterparts in internationalisation processes (e.g., Jarosiński, 2013) and that there are differences in their performance (Koles and Kondath, 2014; Nowiński and Rialp, 2013). Despite the growing attention to this topic (Dikova et al., 2016), a clear and comprehensive explanation of these differences still has not been proposed. It is, therefore, necessary to understand the context-specific features of CEE firms both when they tend to implement the best western practices and when they create their unique set of internationalisation strategies, based on local ways of conducting business and past experiences, such as their socialist legacy (e.g., Cuervo-Cazurra and Genc, 2008; Ramamurti, 2012). For instance, what is the effect of the institutional ecosystem on CEE firms' internationalisation: does it hold them back or provide a reason to move forward (e.g., 
Contractor, 2013; Luo and Tung, 2007)? Next, former planned economy traditions and legal constraints on private commercial activity constitute unique circumstances that affect CEE economies and differentiate them from other emerging economies (e.g., Contractor, 2013; Cuervo-Cazurra and Genc, 2008; Dana, 2010). Consequently, we posit the following research question: What does the discipline know about processes, influential variables and outcomes of internationalisation of companies from CEE countries? Our research question puts our study in a particular stream of international business research, i.e. strategic approach (e.g., Yamakawa et al., 2008).

We adopted a broad and well-established definition of internationalisation as the strategic process of increasing involvement in international operations across borders (Welch and Luostarinen, 1998). As such, internationalisation is viewed as a major dimension of firms' strategy processes, determining the on-going development and change in the firm's scope, business idea, action orientation, organising principles, nature of managerial work, dominating values and converging norms (Melin, 1992). Accordingly, research focuses on strategies or behaviours adopted by the firms that internationalise, the intervening elements and evaluation (Rumelt et al., 1994). Lately, such an approach has been largely adopted in the context of emerging economies (e.g., Hoskisson et al., 2000; Wright et al., 2005). If broadly defined, the set could be said to encompass CEE countries as well.

Regarding the contextual set of the study, it should be mentioned that the area corresponding to Central and Eastern Europe (CEE) has an age-old tradition of bringing together Asia and Europe. Centuries ago, trade via the Balkans and the Silk Road carried goods, ideas and culture between the continents. The internationalisation of firms from CEE countries has again become important; furthermore, the region shares borders with some of the world's most dynamic economies, including Russia - one of the Brazil, Russia, India and China (BRIC) group. This paper focuses on the internationalisation of firms from CEE. For the purpose of our research, we adopted the International Monetary Fund (IMF) list of CEE countries, which includes 21 countries from the Warsaw Pact group as well as the new republics of former Yugoslavia. Although the internationalisation of European firms has received growing attention (Ratten et al., 2007), research results are still contradictory (Meyer and Gelbuda, 2006). This is deemed to be an important area of research, given the particularities of transitional economies in CEE (Dana, 2010).

This study aims to systematise the knowledge about internationalisation processes and the related strategies in CEE firms, i.e., companies originally located in CEE countries (outward internationalisation). With the objective of contributing to the understanding of how internationalisation takes place in CEE - where pre-transition international experiences were very limited (Zapletalová, 2015) - a systematic literature review methodology was adopted. The analysis is based mainly on quantitative studies; the selection process shall be explained 
in detail in the methodology section below. Sample analysis revealed that the topic is relatively "young" and that a general approach to the internationalisation of CEE firms has been developing only since 2000. As regards the researchers' interest in more specific elements and deeper process analysis, it dates only from 2007. With regard to the geographical distribution of the studies, Poland $(\mathrm{N}=17)$ and the Czech Republic $(\mathrm{N}=7)$ were most frequently analysed.

Distinct and interesting elements within the research clusters were observed. The first interesting fact is that internationalisation from this part of the world is mostly limited to exporting and a heavy reliance on personal and inter-firms networks (Wright \& Dana, 2003). The second element concerns the factors boosting or igniting internationalisation. They range from external economic circumstances, such as hostile home-country factors or proper market-seeking motives to internal motivations such as governance and ownership structure, experience etc. Finally, if internationalisation is considered to be an active element and a boosting factor for the development of a firm, it may also represent an element of risk and such a decision needs to be weighted appropriately. Compared to firms from developed economies, where internationalisation covers a broad spectrum, internationalisation of firms from CEE is limited by the resources and capabilities available, which in turn limits their results.

The article is structured as follows. First, it describes the research methods used. Then, it offers descriptive statistics about the dataset of the reviewed articles. Third, it analyses the content of these items by aggregating them into three different clusters of arguments. Finally, it synthesises the main results from the analysis and then proposes some avenues for the future research in this area.

\section{Method}

We adopted the systematic method for our literature review (Cook, Mulrow, \& Haynes, 1997; Denyer \& Tranfield, 2008; Tranfield, Denyer, \& Smart, 2003). This is a research method that emerged in the UK medical profession to produce better evidence-based research. Since then, it has been extensively used in many fields, including management analysis (e.g., Thorpe, Holt, Macpherson, \& Pittaway, 2005). This method aims at collecting and linking together as many already existing relevant studies as possible by adopting a structured and systematic process of reviewing the literature (Callahan, 2014).

Consistent with several recent systematic assessments of the management literature (Abatecola et al., 2013; Caputo, 2013a, 2013b; Mysen, 2013), a set of criteria was established. Moreover, a panel of experts was formed to define the field of research, choose 
keywords and the database, and to finally develop the inclusion and exclusion criteria. The research string was developed through previous knowledge of the international business literature and through the guidance of our panel of experts in our field of study.

The following set of criteria was established: the review comprises English-language peer-reviewed journal articles only. "EBSCO Host - Business Source Complete" was used as the database and abstracts as the target. The substantive relevance of the articles focusing on internationalisation strategies was ensured by requiring all the selected articles to contain the words "International* AND firm* OR compan* OR corporat* OR business*". Several searches for alternative strings (e.g., including specific strategies such as export, FDI, etc.) were performed and the chosen search string was set to include the largest number of studies, which broadened the review's scope. In order to ensure geographical relevance the names of all CEE countries were included in the search string. This deserves further explanation. There is no agreement in academic literature or economic policy on the list of CEE countries. For example, the OECD considers former socialist countries, which extend east from the border of Germany and south from the Baltic Sea to the Greek border and lists 15 countries (OECD, 2015), and consulting companies (such as KPMG or Roland Berger) variably consider 17-19 countries to be in the CEE region (adding former CIS countries, such as Belarus, Moldova, Russia, and the Ukraine), while the European Union (EU) usually considers only EU-member states. In this realm of unlike definitions it was agreed to adopt the list that was at the same time broad and reputable. Relying on the list of the International Monetary Fund (IMF, 2015), a total of 21 countries were included in the search string. The following is the second order search string: "CEE* OR Albania* OR Belarus* OR Bosni* OR Herzegovin* OR Bulgaria* OR Croatia* OR Czech* OR Eston* OR Hungar* OR Kosov* OR Latv* OR Lithuan* OR Moldov* OR Montenegr* OR Macedon* OR Poland OR Polish OR Romania* OR Serbia* OR Slovenia* OR Slovak* OR Ukrain*”. This approach resulted in providing the highest number of articles to be considered: a total of 907.

The selection process followed a step-by-step research protocol (Table 1), which is consistent with previous research (Abatecola et al., 2013; Eberlin \& Tatum, 2005; Mysen, 2013). For the first step, each researcher selected a list of pertinent articles by a preliminary read of all the titles. To ensure inclusiveness and limit human error, all the resulting records were then matched and disagreements were solved through panel discussions. As a result, the number of papers discharged in this preliminary screening was significant and only 96 papers were kept for the subsequent steps. Similar drops in numbers are common in systematic literature reviews (e.g., Abatecola et al., 2013; Caputo, 2013a) and in this case it was ascribable to the following reasons: 
1) Pertinence: Although many papers deal with international companies and trade, their particular focus is not the internationalisation process. At this point a further clarification is required. As our strategic approach included broad definition of internationalisation (Welch and Luostarinen, 1998), the researchers were only interested in papers which primarily focus on firms' strategy processes, on-going developments and changes (Melin, 1992). Some articles were therefore excluded as they have a purely economic perspective, pointing to positive conditions in the host society that can hinder/facilitate the trade balance. Other papers consider aspects associated with international or multinational companies, such as managerial culture, incentives, and intercultural management, but not internationalisation itself as a strategic process i.e., the international companies have been only considered as a context of the study and therefore excluded from the sample (e.g., Dabić et al., 2012).

2) Coherence with the research objective: it was aimed to review the processes, forms and strategies of internationalisation of companies originally located in CEE countries, i.e. outward internationalisation. Most of the papers that were not discarded for the criterion of pertinence focus on the internationalisation processes of Western or international companies where CEE countries were the targets of internationalisation, i.e. inward internationalisation. Accordingly, all studies dealing with the behaviour of subsidiaries were excluded.

As a second step, the selected articles were further scanned by reading all their abstracts to ensure substantive context. Therefore, the research team looked for articles that correlate with the research theme. Similarly to step 1 and for the same reasons, each researcher selected a list of pertinent articles after reading all the abstracts. Then, the lists were compared, by adopting the criteria used in step 1, and (through a series of panel discussions) a final list of selected articles for final reading was agreed. As a result, 45 articles were selected to be read thoroughly.

Our third step was to read every selected article in full. Again, each author did so, in order to agree on a final list of relevant articles to be reviewed. At this stage papers were evaluated based on criteria similar to those used previously and according to their quality. After reading the full text, some papers were not found to be up to academic standard. In line with the established procedures in systematic literature reviews (e.g., Abatecola et al., 2013) and to avoid reporting flawed findings, the articles of dubious academic quality and rigour were excluded.

According to the above criteria - pertinence, coherence and quality - 15 papers were excluded after a panel discussion. The final number of articles analysed was 30, a number 
consistent with the results of reviews published in management journals (Abatecola et al., 2013; Brooks, 2011; Campbell-Hunt, 2000; Caputo, 2013a, 2013b; Gittins \& Fink, 2015; Eberlin \& Tatum, 2005; Mysen, 2013).

Consistent with recent systematic literature reviews, articles were analysed in a qualitative fashion (e.g., Barclay et al., 2011; Pittaway and Cope, 2007). An excel dataset was set up to collect all the qualitative information on the selected papers. Such procedure helped the researchers to investigate evolutionary trends and topics of interests through the use of adhoc pivot tables. Moreover, the qualitative analysis of text was supported by the software of nVivo. This software is a widely used tool in qualitative research that allows the researcher to code and categorise contents (e.g., Duarte Alonso \& Bressan, 2014; Söderqvist \& Chetty, 2013). Each paper was uploaded in the software and was re-read by the researchers. During the reading, each article was coded according to the identified clusters. In line with the established procedures in Systematic Literature Review (e.g., Thorpe et al., 2005; Tranfield et al., 2003) the articles were allowed to be part of more than one cluster. For example, Musteen, Francis \& Datta (2010) discussed both firms' selected behaviours/processes for internationalising as well as the influential variables involved in it; as a consequence their paper was included in two clusters, i.e. Internationalisation Processes and Variables. Within each paper, relevant parts of the text were selected and tagged with keywords representing their content. A dynamic tagging procedure was adopted, i.e. the researchers allowed new tags to be included during the process of reading articles. This allowed flexibility in categorising information and helped in reducing biases that possibly can arise from a rigidly pre-set system.

\section{- - - PLEASE INSERT TABLE 1 ABOUT HERE - - -}

\section{Findings}

According to their content and consistent with previous research, articles from the dataset were grouped in two categories (Gonzalez-Loureiro et al., 2015).

First, articles were assigned to three clusters representing different aspects of internationalisation strategy seen as a process. The clusters could be identified using an engineering metaphor: the process itself ("Internationalisation Processes"), the inputs of such a process or the influential intervening variables ("Internalisation Variables"), and the outputs ("Internalisation Outcomes"). Articles assigned to the "Internationalisation Processes" cluster focus on specific approaches, behaviours, and strategies adopted by local firms in order to internationalise. Moreover, they include explanations of each specific choice and comparisons. In other words, these contributions are concerned with the chosen strategies and 
the rationale behind them, i.e. the process itself. Studies belonging to the "Internationalisation Variables" cluster investigate elements and influential factors that may affect the success or failure of an internationalisation process. In other words, adopting our metaphor, these contributions deal with the "inputs" that can be used in a specific internationalisation process, but are less interested in the process itself. Finally, the third aspect highlighted, i.e., the "Internationalisation Outcomes" cluster studies the consequences of internationalising, i.e. potential benefits or risks and drawbacks. This cluster is theoretically interesting because it contains contributions which are intent on studying the consequences of internationalisation and evaluating them, which approach is quite rare in the literature (Yamakawa et al., 2008).

Within each cluster articles were also differentiated based on the type of internationalisation strategy investigated. As a result, the articles were assigned to four categories. The first category was labelled as "Generic", meaning articles that were not focusing on any particular form of internationalisation but rather on investigating the internationalisation path of the firms. Then, the articles were grouped focusing on three specific strategies encountered in the analysed literature. The second category was labelled as "Export", relating to articles that specifically investigated forms of export strategies for internationalisation. The third category was labelled as "OFDI" as articles in this category were focusing on Overseas/Outward Foreign Direct Investment. Finally, the fourth category that emerged was labelled as "Network"; articles in this category investigated network strategies, such as strategic alliances and joint ventures (Dabic and Bach, 2008; Ratten et al., 2007).

Not surprisingly, the Internationalisation Processes cluster was the most investigated $(\mathrm{N}=20)$, followed by Internationalisation Variables $(\mathrm{N}=12)$ and Internationalisation Outcomes $(\mathrm{N}=10)$. Table 2 shows the distribution of articles between the dimensions of clusters. To our surprise, there were no studies related to influential variables or outcomes of internationalisation and with a focus on OFDI.

\section{- - - PLEASE INSERT TABLE 2 ABOUT HERE - - -}

Within the population, 22 articles used a quantitative approach, five used a qualitative approach, two articles used a mixed methodology, and only one was conceptual. It is noteworthy that articles analysing internationalisation variables and outcomes mostly used a quantitative approach while articles investigating internationalisation processes adopted diverse methods. 
As shown in Figure 1, the research on internationalisation by CEE firms presents a constant trend. The number of publications reaches a peak in 2015, when six were published, between 2000 and 2010 the number fluctuates, which is followed by a substantial increase between 2010 and 2015. This trend is consistent with the growing interest in the topic after the opening of CEE economies as a consequence of the fall of the Berlin Wall, and the opening of CEE economies to EU integration processes, which most probably influenced English production of studies from those countries.

\section{- - - PLEASE INSERT FIGURE 1 ABOUT HERE - - - - - - PLEASE INSERT FIGURE 2 ABOUT HERE - - -}

Considering how the different clusters within the dataset were distributed over the years, Internationalisation Processes has been consistently developing since 2000, while the interest in Internationalisation Variables and Outcomes has been growing since 2007. Moreover, while scholarly attention to Internationalisation Processes has been equally distributed over the years, the number of studies included in the other two clusters appears to be more unstable.

\section{- - - PLEASE INSERT TABLE 3 ABOUT HERE - - -}

As far as the sources of the articles are concerned, a number of journals have published articles on this stream of research. With no intent of entering the debate about how journals are evaluated and ranked, it was decided to compare the journals according to three of the main sources: the SCImago H-Index, the SCImago SJR and the JCR Impact Factor. Except for three journals, which are tied to universities in CEE countries, all the research on this topic that was found appears in reputable journals with impact.

With regards to the geographical distribution of studies, out of 21 searched countries, the literature suggests that internationalisation has only been investigated in ten. As per Table 4, Poland $(\mathrm{N}=17)$ and the Czech Republic $(\mathrm{N}=7)$ were the most analysed countries. Seven studies out of 30 analysed two or more countries.

\section{- - - PLEASE INSERT TABLE 4 ABOUT HERE - - -}

\section{Discussion of clusters}

In this section, the main content of the different clusters is analysed. 


\subsection{International Processes}

Firms internationalising from a CEE country face increased uncertainty in the competitive environment consisting of firms from all over the world and different dimensions, all of which results in different internationalisation paths (Dana et al., 2004). Articles included in this cluster analyse a company's internationalisation decision, its actions and its dynamic processes. Four streams of studies emerge from our analysis.

The first stream of studies focuses on the modes and strategies that CEE firms deploy to internationalise (Śliwiński, 2012; Stare, 2002; Zapletalová, 2015). Among these, the dualism between the Uppsala internationalisation model (Johanson and Vahlne, 1977; Johanson and Wiedersheim - Paul, 1975) and the born global, or international new venture, model (Madsen and Servais, 1997) dominates the debate. On the one hand, some studies confirm how the stage approach, where the company gradually internationalises, would better represent the internationalisation behaviours/strategies of CEE firms (Blanke-Lawniczak, 2009; Malo and Norus, 2009; Sass, 2012; Stare, 2002). On the other, some confirm speculations associated with the born-global approach, where companies are initially conceived for international competition (Jarosiński, 2013; Nowiński and Rialp, 2013). Interesting, although somehow contradicting, results emerge from the analysis of the born global firms. Although born global firms face both tangible and intangible resource constraints, due to the limited international business experience and international social capital (Nowiński and Rialp, 2013), such companies largely contributed to the overall internationalisation of Poland in the aftermath of transition from 1989 to 2003 (Cieślik and Kaciak, 2009). Simultaneously, the unstable operating environment during the early stages of the transition period discouraged entrepreneurial start-ups initially involved exclusively in the domestic market from launching export sales because of their perception of the high risks involved in international operations (Cieślik and Kaciak, 2009; Nowiński and Rialp, 2013).

In the realm of idiosyncratic forms of internationalisation, some similarities emerge across different countries. Fonfara (2011), for example, explains how four different patterns emerge from the internationalisation of Polish firms. "Type A - Active" firms are those engaging in formal internationalisation processes by creating a network of formal relationships with foreign firms. "Type B - Submissive" firms engage in more spontaneous internationalisation processes through a passive approach to the creation of a network of relationships. "Type C - Independent" firms engage in formal internationalisation process but with a high closeness to cooperation. Finally, "Type D - Distrustful realist" firms engage in spontaneous internationalisation processes despite being closed to cooperation. Vissak \& Masso (2015), identified 13 main types of export patterns and 11 sub-patterns. These authors showed that nonlinear internationalisation is the prevalent form for Estonians firms. 
Reviewing internationalisation processes of Czech companies, Zapletalová (2015), found five emerging models. "Model A" firms are relatively young and small companies with a fast but geographically limited internationalisation. "Model B" firms adopted a stage approach and gradually internationalise. "Model C" firms are similar to the previous models concerning size and age but engaged in a rapid internationalisation in multiple foreign markets (the born global). "Model D" (large) and "Model E" (SME) firms consist of older, established companies that have entered a limited number of markets at a later stage.

As far as specific internationalisation strategies are concerned, the dominant form of internationalisation is export (Masso and Vahter, 2014; Śliwiński, 2012; Stare, 2002). Śliwiński (2012) identified that $44 \%$ of the companies followed export strategy through the foreign distributor, $28 \%$ set up sales subsidiaries in foreign markets, $16 \%$ built or acquired production plants, and $12 \%$ operated in the form of a joint-venture. Such findings confirm previous studies showing how the service sector of the Czech Republic, Hungary and Slovenia entered foreign markets first through exporting, and engaging in OFDI at a later stage (Stare, 2002). Interestingly, Slovenia was the first of the analysed countries to begin with OFDI, a result that can be attributed to the greater openness of its economy and larger autonomy of its firms. Case studies from Estonia, Latvia, Lithuania and Poland confirm a step-by-step pattern of internationalisation. Firms began global expansion in similar (transition) economies via exports of less expensive and premium products, later entering distant markets via joint ventures or acquisitions (Blanke-Lawniczak, 2009; Malo and Norus, 2009; Masso and Vahter, 2014). Some scholars have been focusing their attention on comparing internationalisation strategies of SMEs and large companies - revealing more similarities than differences in their patterns (Svetličič et al., 2007). Innovative SMEs internationalise more frequently and at a higher level even in transition economies (Sass, 2012).

The second stream of research involves networks and alliances. Wright and Dana (2003) focus on the role and use of networks and alliances in the internationalisation process. Networks and alliances are very relevant in transition economies that do not provide sufficient support to businesses; in such a case, companies from those countries seek partners that can provide the required capabilities to overcome the tangible and intangible constraints for internationalisation (Hitt et al., 2000). Indeed, the lack of certain services or capabilities in the home country can predict what the companies would look for in selecting networking strategies (Hitt et al., 2000). As far as our dataset is concerned, the first study traces back to 2000 and it is related to the stream of research clustered as "Network". Hitt et al. (2000), surveying 202 managers, studied the international partner selection of firms from emerging and developed countries. Although that study does not strictly relate to CEE economies, it 
draws findings from Poland and Romania among others. Compared to firms from developed countries, firms from CEE recognised how the capability for quality was a major determinant in partner selection. Firms from a transition market look for partners willing to transfer managerial and technical skills (Hitt et al., 2000). A significant deficit in transitional economies such as Poland and Romania is the lack of financial capital and the lack of infrastructure to provide access to capital. Many firms in these countries, therefore, develop strategies (for instance, strategic alliances) designed to garner infusions of equity capital (Hitt et al., 2000; Nowiński and Rialp, 2013).

Such findings lead us to the debate of the third stream of studies, centred on specific elements and motives that may influence the selection of the internationalisation strategy among CEE firms. We identified a dichotomy between hostile home-country factors that create the need for internationalisation (Hitt et al., 2000; Malo and Norus, 2009; Nowiński and Rialp, 2013), and market seeking motives (Sass, 2012; Śliwiński, 2012; Svetličič et al., 2007; Wilinski, 2012), which guide the search for international expansion. Moreover, hostcountry related factors, such as political risks, instability and the lack of transparency are the highest barriers for OFDI, regardless of the dimension of the firm (Sass, 2012; Svetličič et al., 2007). Not surprisingly, SMEs are more vulnerable to factors related to financial access than large firms. Among the hostile home-country factors, the most prominent seems to be the lack of intangible assets (Gorynia et al., 2015).

The fourth stream of studies emerges among those analysing the role of geographical and cultural proximity in the internationalisation process. Such studies find that geographic scope choices where mostly based on the similarity of the market, culture (Malo and Norus, 2009; Stare, 2002; Svetličič et al., 2007) and language (Musteen et al., 2010; Sass, 2012). Stare (2002) confirmed how the geographical location of OFDI indicates that physical and cultural proximity to a large extent determined decisions in the early stages of investing abroad. Indeed, knowledge of a language, personal contacts and similarity of business culture play an especially important role in the internationalisation process of CEE firms (Sass, 2012; Stare, 2002). Firms sharing a common language with their international ties can internationalise faster than firms that do not share a common language (Musteen et al., 2010); for example, Polish companies were found to invest mostly in non-EU developing countries of Central and Eastern Europe (Gorynia et al., 2013). As conceptualised in the Uppsala model, such findings may offer an important clue to understanding why SMEs which were pursuing an internationalisation strategy initially moved to countries that are culturally similar or in close geographical proximity (Malo and Norus, 2009; Sass, 2012). The role of previous experience in operating in similar environments was also found to be a determinant (Gorynia 
et al., 2013). Radlo and Sass (2012) analyse the development of OFDI in the Czech Republic, Hungary, Poland, and Slovakia, finding that investments were geographically distributed according to similar needs. For example, tax optimisation and financial benefits are the major characteristics of OFDI projects located in Cyprus, Luxembourg, the Netherlands, Switzerland, and the United Kingdom. Projects located in central, south-eastern, and eastern Europe, Scandinavian countries, Germany, and other western European countries, are mostly motivated by the willingness to improve the market power of the company and the desire to enter new markets.

\subsection{International Variables}

This cluster gathered contributions with the primary aim of investigating elements that either improve or reduce the odds of success for an internationalisation process. A remarkable number of studies, produced by prolific authors, adopted a network perspective (Manolova et al., 2010, 2014; Musteen et al., 2010; Musteen, Datta and Butts, 2014; Musteen, Datta and Francis, 2014). In two subsequent papers, Manolova, Manev and Gyoshev $(2010,2014)$ analyse processes of internationalisation of new and small ventures in the transition economy of Bulgaria. Such companies are likely to face resource constraints and institutional voids that can be overcome through intense network relationships (Smallbone and Welter, 2006). In their first study (Manolova et al., 2010), the authors investigate the impact of the entrepreneur's network size and inter-firms networking on internationalisation, finding an active relation only with the network size. However, when the age of the firm was added to the model, the inter-firms network became impactful for "younger firms". This indicated that as the firm grows older and more stable in the internationalisation path, its domestic ties produce fewer benefits while the personal network of the entrepreneurs remains influential. In their second study (Manolova et al., 2014) the attention is shifted onto other types of network connections, in particular, the financial network. The presence of a financial network, as advisors, investors, and in general connections with financial institutions, is positive for the internationalisation process, and its impact is greater as the ventures grows larger. These network relations seem to be able to sustain the process of internationalisation even in a stable and structured phase of internationalisation. Other scholars (Musteen et al., 2010; Musteen, Datta and Butts, 2014; Musteen, Datta and Francis, 2014) present a deep network analysis of the CEO's network in Czech SMEs. In Musteen et al. (2010), the CEO's network is related to two distinct internationalisation outcomes i.e., speed of internationalisation and performance of the first international venture. The only booster of the above element seems to be, quite reasonably, sharing a common language with their international ties. The internationalisation speed is facilitated by easy verbal exchanges and, probably, a common background. The actual performance of the SME, however, paints quite a different picture. Firstly, relying 
primarily on personal sources of information, i.e., the individual ties of the CEO, rather than on professional or industry-related ties, led to a weaker performance of the internationalisation process. Secondly, the geographic diversity of the relationships is positively associated with the international performance and this means that such geographically dispersed networks can help to exploit international opportunities. In their second work (Musteen, Datta and Butts, 2014) the network of the CEO is analysed from the traditional perspective of social capital dimension (Adler and Kwon, 2002). According to Burt (1997) and his structural hole approach, small and medium firms' CEOs from the Czech Republic, which are characterised by low-density networks, should have greater access to varied knowledge and information about foreign markets, and thus achieve a better internationalisation performance. However, this hypothesis is not supported by the data, showing that the density is not an element that has an impact. When a CEO interacts with network ties in several foreign countries, he/she is likely to develop a broader knowledge base about international markets and existing competitive conditions and, similar to the previous study, this condition is confirmed. Finally, CEO's international ties intensity and the his/her level of knowledge about the foreign market at the time of internationalisation are positively linked. Finally, the focus of the third work is only the early internationalisation (Musteen, Datta and Francis, 2014). A more general definition of the network is assumed and the findings indicate that such networks are likely to be more useful when firms emphasise technological innovation. In the whole cluster, however, internationalisation is mostly translated as exporting and a major void exists for the other types of internationalisation. This lack is likely to be related to a limited number of firms that internationalise in a more structured form than the basic exportation channel. Firms in transition economies indeed are more vulnerable than those in fully developed countries and face higher competition risks. Nevertheless, since such initiatives are documented, significant attention on these phenomena would be appropriate.

The second stream in this cluster adopts an internal perspective in analysing the factors of success and failure in internationalisation processes. One element examined is the corporate governance and the ownership structure. Filatotchev, Isachenkova and Mickiewicz (2007) used a sample of 157 large firms in the top 500 and 250 in Poland and Hungary, respectively. The results show that managerial independence in strategic decision-making may be a crucial driver of internationalisation. Large firms indeed benefit from independence in internationalisation matters too. Possibly opposite results are found by another comparative study carried out in Estonia and Slovenia. Hobdari, Gregoric and Sinani (2011) suggest that firms under the control of the insider owners are, on average, more internationalised. State control, on the other hand, hampers internationalisation efforts; however, these results only 
compare the public and private nature of ownership and the sample does not consist of large companies. The second aspect is the experience of the firm in dealing with the internationalisation process and the propensity and knowledge of its entrepreneur. In a cluster of Polish firms, Cieślik, Kaciak and Thongpapanl (2015) found that export experience and the performance of such activity have an inverted S-shaped relationship. Thus, performance increases at the beginning of the internationalisation process and in a later stage when the position in international markets is consolidated. However, performance is reduced during the "middle" phase. Similarly, a market spreading strategy, when more than one single market targeted, is more beneficial to exporting firms than a market concentration approach. Also based on a Polish sample, Nowiński and Rialp (2013) indicate that global and international experience (international orientation of entrepreneurs) is more important in the internationalisation process than is the initial dotation of the international social capital of the same subjects.

The third and final stream pays attention to external conditions that may favour the internationalisation. Adopting a rather economic approach, Michalski (2014) suggests that for the Polish economy internationalisation is driven by the effect of investment projects of foreign affiliates, especially those cooperating with the broadly defined automotive sector. That author assumes that this to some extent confirms the validity of the controversial paradigm called corporate (neo)colonialism of the Polish economy. Hagemejer and Kolasa (2011) only slightly touch upon the paradigm of successful internationalisation, i.e., a model of learning by exporting. They support the opposite view, i.e. that internationalisation leads to a superior performance for the firm. Vissak and Masso (2015) study Estonia's export patterns challenging the assumption about the traditional paradigm in the international business literature i.e., the most commonly used premise of a simple internationalisation model (à la Uppsala) or the instantaneous global expansion (à la born global). The trading data show that these models are the least assumed by the Estonian exporters and that their evolution in the global market is rather non-linear, i.e. internationalisation processes are followed by partial or total de-internationalisation. They assume that such patterns are due to the business cycle of the firm and probably as a result of the relatively limited access to international markets. Contributions dealing with hostile home countries conditions or, at least, the perception of their presence, reveal a pattern. Such element does not only "ignite" the internationalisation process, as already explained in the previous cluster, but may also increase the "strategic attention" and thus ameliorate the odds for a successful internationalisation. Indeed, network relations are likely to be more useful when SMEs face severe environmental conditions in their home country (Musteen, Datta and Francis, 2014). Nowiński and Rialp's (2013) study draws similar conclusions; the perception of a small or almost non-existent domestic market 
coupled with unfavourable conditions offered by local distributors are boosters of internationalisation.

\subsection{International Outcomes}

Finally, the third cluster is interested in consequences of internationalisation, rather than in how the process took place. However, many contributions in this cluster assumed an economic explanation of such results and this also represents our first stream of research. Most of their results show evidence that is consistent with Melitz's model (2003), a relatively recent contribution that suggests self-selection by more productive firms to internationalise (Cieślik, Michałek, et al., 2015; Hagemejer and Kolasa, 2011; Malo and Norus, 2009; Masso and Vahter, 2014; Michalski, 2014; Ruzzier and Ruzzier, 2015) (Cieślik, Michałek, Michałek \& Mycielski, 2015; Hagemejer \& Kolasa 2011; Malo \& Norus 2009; Masso \& Vahter 2014; Michalski, 2014; Ruzzier \& Ruzzier, 2015). These contributions report a broad range of benefits, or positive consequences related to the internationalisation choice; Hagemejer and Kolasa (2011) based their study on a Polish trade dataset and found that general exporters are significantly larger with regards to output and employment, have higher ratios of capital per worker and pay higher wages than non-exporters. Such findings seem to represent a common pattern across many transitional economies. Indeed, the level of productivity, firm size, the share of university graduates in productive employment, spending on R\&D activities, and foreign ownership are all aspects that were found to be higher among exporters in a crosscountry comparison in the Baltic region (Estonia, Latvia, and Lithuania) and within the Eastern European region (the Czech Republic, Hungary, Poland, and Slovakia) completed by Cieślik et al. (2015). Ruzzier and Ruzzier (2015) also indicate that a Slovenian exporter has a bigger size regarding full-time employees, sales, and selected types of resources. However, there are some possible moderating factors. For example, exportation mainly affects segments of the Polish economy with a higher capital intensity and with a stronger emphasis on technology sophistication (Michalski, 2014). Masso and Vahter (2014) found that large exporters' productivity benefits from concentrating on their core export products. Simultaneously, small firms with fewer than 50 employees, on average, do not achieve this effect.

The second stream still highlights other benefits and positive outcomes of the internationalisation, but these are of an intangible and managerial fashion. International business research considers export and financial performance as interrelated organisational outcomes of the firm's strategic dynamics (Djankov and Murrell, 2002). For this reason, Filatotchev, Isachenkova and Mickiewicz (2007) indicate that structured corporate governance can directly influence internationalisation that in turn shows positive outcomes in 
terms of financial performance. Introducing institutional investors in the ownership, for example, can improve performance by offering the financial resources needed for restructuring, access to know-how, marketing, and organisational skills and all these elements directly or indirectly can improve performance. Musteen, Datta and Butts (2014) also show that internationalisation is sought through network skills as a matter of higher performance for SMEs in the Czech Republic. Finally, Fonfara (2011) explains different approaches to internationalisation, considered as engagement with foreign partners and planned procedures, and their outcomes. The winning strategy seems to be a planned approach to the network strategy; this leads to better performance due to clear goals and strategies set when engaging with partners.

Not withstanding the above, internationalisation does not bring only positive outcomes. Such an activity is risky and may "distract" precious resources form the domestic market to a more uncertain and competitive environment of the foreign markets. Thus, the final stream focuses exactly on this element, i.e. the risk of internationalisation. Vissak and Masso (2015) through their analysis of Estonian exporting patterns conclude that such activity is often dropped even by "sound and profitable" firms that deliberately decide to go back to the local market. Moreover, and quite surprisingly, exporters' survival rate in a composite picture seems to be lower than non-exporters' survival rate. The inferred interpretation is that exporting and internationalisation in general are still riskier than focusing on local activities in a transition economy. Focusing on new companies and start-ups in the biotechnology sector of Estonia, Latvia, Lithuania and Poland, Malo and Norus (2009) recommend a gradual approach to internationalisation. Incremental approach, as an alternative, if endorsed forcefully, can be harmful to the continued existence of start-ups. The risk of internationalisation seems to be mitigated by a cautious and gradual path, also confirming the Uppsala model's validity. The studied firms have begun their global expansion via exports to end in distant markets via joint ventures or acquisitions. This stream of research, even if it is represented by a rather small number of papers, is a reliable avenue for future research, especially for transition economies where the benefits of internationalisation can be offset by the sunk cost and risk implied in the process.

\section{Conclusions and Implications for Future Research}

CEE firms seem to adopt both the Uppsala model and the born-global approach. According to the presented review, CEE firms seems seem to internationalise only in similar countries; the concept of proximity is fundamental in deciding where to expand. Proximity is intended as physical proximity (geography), cultural proximity and language proximity. 
Compared to firms from developed economies, the internationalisation of which has a broad spectrum, internationalisation of CEE firms is limited by the resources and capabilities available to them and the results are more limited. Hostile home-country conditions represent an interesting motive for internationalisation of CEE firms, and this aspect should be researched in more detail. Further research should take into account that internationalisation of different industries results in different added value per employee and number of workers (Ruzzier and Ruzzier, 2015). Also, more strategies should be studied: joint ventures, strategic alliances - most of the studies analyse export or FDI. Primary emphasis should be placed on the risk of internationalisation, not only on the benefits of general incorporation of CEE countries in the EU area or on the different factors that drive internationalisation of firms' several pillars becoming the source of economic growth and change.

While this paper contributes to our knowledge and research results about internationalisation by clarifying the newly emerging area of internationalisation and its theoretical basis by applied methodology, the result of the subject matter selection of keyword search and the citation analysis could be considered as the primary limitation of the paper. Additionally, the results of this study are based only on the papers covered by the EBSCO database. Further research can, therefore, be performed for Web of Science and SCOPUS to consider the differences in the covered publications. Finally, investigations into the other factors associated with internationalisation, e.g. mode of entry or the influence of firm's size on internationalisation are necessary. Different theories, such as internationalisation theory, the eclectic paradigm, RBV and the International New Venture theory stage model of internationalisation etc., diverse patterns and ontological premises and a more holistic approach need to be applied to further determine the stream research results.

\section{References}

Abatecola, G., Caputo, A., Mari, M. and Poggesi, S. (2013), "Real Estate Management: Past, Present and Future Research Directions”, International Journal of Globalisation and Small Business, Vol. 5 No. 1/2, pp. 98-113.

Adler, P.S. and Kwon, S.-W. (2002), “Social capital: Prospects for a new concept”, Academy of Management Review, Vol. 27 No. 1, pp. 17-40.

Barclay, S., Momen, N., Case-Upton, S., Kuhn, I. and Smith, E. (2011), "End-of-life care conversations with heart failure patients: a systematic literature review and narrative synthesis", British Journal of General Practice, Vol. 61 No. 582, pp. e49-e62.

Blanke-Lawniczak, K. (2009), "Marketing Dynamics and Management Excellence: The 
Sources of Successful Internationalization of a Food Processing Company from a Transition Economy (Case: MASPEX_Poland).”, Journal of International Food \& Agribusiness Marketing, Vol. 21 No. 2/3, pp. 134-148.

Brooks, M.E. (2011), “Management indecision”, Management Decision, Vol. 49 No. 5, pp. 683-693.

Burt, R.S. (1997), “The contingent value of social capital”, Administrative Science Quarterly, Vol. 42 No. 2, pp. 339-365.

Callahan, J.L. (2014), "Writing Literature Reviews A Reprise and Update”, Human Resource Development Review, Vol. 13 No. 3, pp. 271-275.

Campbell-Hunt, C. (2000), "What have we learned about generic competitive strategy? A meta-analysis", Strategic Management Journal, Vol. 21 No. 2, pp. 127-154.

Caputo, A. (2013a), “A Literature Review of Cognitive Biases in Negotiation Processes”, International Journal of Conflict Management, Vol. 24 No. 4, pp. 274-398.

Caputo, A. (2013b), "The Third Who Joins a Negotiation: a Systematic Review of the Literature", International Journal of Business and Globalisation, Vol. 10 No. 3, pp. $256-277$.

Cieślik, A., Michałek, A., Michałek, J.J. and Mycielski, J. (2015), "Determinants of Export Performance: Comparison of Central European and Baltic Firms.", Finance a Uver: Czech Journal of Economics \& Finance, Vol. 65 No. 3, pp. 211-229.

Cieślik, J. and Kaciak, E. (2009), “The Speed of Internationalization of Entrepreneurial StartUps in a Transition Environment", Journal of Developmental Entrepreneurship, Vol. 14 No. 4, pp. 375-392.

Cieślik, J., Kaciak, E. and Thongpapanl, N. (Tek). (2015), "Effect of export experience and market scope strategy on export performance: Evidence from Poland.”, International Business Review, Vol. 24 No. 5, pp. 772-780.

Contractor, F.J. (2013), “'Punching above their weight': The sources of competitive advantage for emerging market multinationals.", International Journal of Emerging Markets, Vol. 8 No. 4, p. 304.

Cook, D.J., Mulrow, C.D. and Haynes, R.B. (1997), "Systematic reviews: Synthesis of best evidence for clinical decisions", Annals of Internal Medicine, Vol. 126 No. 5, pp. 376- 
380.

Cuervo-Cazurra, A. and Genc, M. (2008), “Transforming disadvantages into advantages: developing-country MNEs in the least developed countries", Journal of International Business Studies, Vol. 39 No. 6, pp. 957-979.

Dabic, M. and Bach, P. (2008), "Understanding the foreign direct investment environments in EU 27+ candidate country Croatia: the current determinants and patterns", International Journal of Entrepreneurship and Innovation Management, Vol. 8 No. 3, pp. 254-271.

Dabić, M., Daim, T.U., Aralica, Z. and Bayraktaroglu, A.E. (2012), “Exploring relationships among internationalization, choice for research and development approach and technology source and resulting innovation intensity: Case of a transition country Croatia.", Journal of High Technology Management Research, Vol. 23 No. 1, pp. 1525.

Dana, L.P. (2010), Entrepreneurship and Religion, edited by Dana, L.P., Edward Elgar Publishing, Cheltenham, UK.

Dana, L.P., Dana, T.E. and Spence, M. (2004), "Public policy and international expansion of high-technology SMEs: a research agenda", International Journal of Entrepreneurship and Innovation Management, Vol. 4 No. 2-3, pp. 116-123.

Denyer, D. and Tranfield, D. (2008), "Producing a systematic review", in Buchanan, D. (Ed.), The Sage Handbook of Organizational Research Methods, Sage, London, pp. 671-689.

Dikova, D., Jaklič, A., Burger, A. and Kunčič, A. (2016), "What is beneficial for first-time SME-exporters from a transition economy: A diversified or a focused export-strategy?", Journal of World Business, Vol. 51 No. 2, pp. 185-199.

Djankov, S. and Murrell, P. (2002), "Enterprise restructuring in transition: A quantitative survey", Journal of Economic Literature, Vol. 40 No. 3, pp. 739-792.

Duarte Alonso, A. and Bressan, A. (2014), "Collaboration in the context of micro businesses: The case of Terracotta artisans in Impruneta (Italy)", European Business Review, Vol. 26 No. 3, pp. 254-270.

Eberlin, R. and Tatum, B.C. (2005), “Conceptual paper: Organizational justice and decision making: When good intentions are not enough", Management Decision, Vol. 43 No. 7/8, pp. 1040-1048. 
Filatotchev, I., Isachenkova, N. and Mickiewicz, T. (2007), “Corporate Governance, Managers' Independence, Exporting, and Performance of Firms in Transition Economies.", Emerging Markets Finance \& Trade, Vol. 43 No. 5, pp. 62-77.

Fonfara, K. (2011), “A typology of company behaviour in the internationalisation process (a network approach).”, Poznan University of Economics Review, Vol. 11 No. 2, pp. 5-25.

Gittins, T. and Fink, M. (2015), "Return migration, informal learning, human capital development and SME internationalization in the CEE region: A systematic literature review", Journal for East European Management Studies, Vol. 20 No. 3, pp. 279-303.

Gonzalez-Loureiro, M., Dabic, M. and Furrer, O. (2015), “A content and comparative analysis of strategic management research in the Baltic area: A research agenda for qualitative studies”, Baltic Journal of Management, Vol. 10 No. 2, pp. 243-266.

Gorynia, M., Nowak, J., Trąpczyński, P. and Wolniak, R. (2013), “The Determinants of Location Choice in the Internationanalization Process of Polish Companies: A Qualitative Study", Journal of Economics \& Management, No. 14, pp. 61-75.

Gorynia, M., Nowak, J., Trąpczyński, P. and Wolniak, R. (2015), “Outward FDI of Polish firms: The role of motives, entry modes and location factors.", Journal for East European Management Studies, Vol. 20 No. 3, pp. 328-359.

Hagemejer, J. and Kolasa, M. (2011), "Internationalisation and Economic Performance of Enterprises: Evidence from Polish Firm-level Data.”, World Economy, Vol. 34 No. 1, pp. $74-100$.

Hitt, M.A., Dacin, M.T., Levitas, E., Arregle, J.-L. and Borza, A. (2000), "Partner selection in emerging and developed market contexts: Resource-based and organizational learning perspectives.", Academy of Management Journal, Vol. 43 No. 3, pp. 449-467.

Hobdari, B., Gregoric, A. and Sinani, E. (2011), "The role of firm ownership on internationalization: evidence from two transition economies.", Journal of Management \& Governance, Vol. 15 No. 3, pp. 393-413.

Hoskisson, R.E., Eden, L., Lau, C.M. and Wright, M. (2000), "Strategy in emerging economies", Academy of Management Journal, Vol. 43 No. 3, pp. 249-267.

IMF. (2015), "IMF Regional Office for Central and Eastern Europe”, available at: http://www.imf.org/external/region/bal/rr// (accessed 20 September 2015). 
Jarosiński, M. (2013), “Contemporary models of Polish firms' internationalization -

Literature and research review", Journal of Economics \& Management, No. 13, pp. 5765.

Johanson, J. and Vahlne, J.-E. (1977), “The internationalization process of the firm-a model of knowledge development and increasing foreign market commitments", Journal of International Business Studies, pp. 23-32.

Johanson, J. and Wiedersheim-Paul, F. (1975), "The internationalization of the firm-four swedish cases 1", Journal of Management Studies, Vol. 12 No. 3, pp. 305-323.

Koles, B. and Kondath, B. (2014), "Strategy development processes in Central and Eastern Europe: a cross-regional perspective", International Journal of Emerging Markets, Vol. 9 No. 3, pp. 386-399.

Luo, Y. and Tung, R.L. (2007), "International expansion of emerging market enterprises: A springboard perspective", Journal of International Business Studies, Vol. 38 No. 4, pp. 481-498.

Madsen, T.K. and Servais, P. (1997), "The internationalization of born globals: an evolutionary process?", International Business Review, Vol. 6 No. 6, pp. 561-583.

Mair, J. and Schoen, O. (2007), "Successful social entrepreneurial business models in the context of developing economies: An explorative study", International Journal of Emerging Markets, Vol. 2 No. 1, pp. 54-68.

Malo, S. and Norus, J. (2009), "Growth dynamics of dedicated biotechnology firms in transition economies. Evidence from the Baltic countries and Poland.", Entrepreneurship \& Regional Development, Vol. 21 No. 5/6, pp. 481-502.

Manolova, T.S., Manev, I.M. and Gyoshev, B.S. (2010), "In good company: The role of personal and inter-firm networks for new-venture internationalization in a transition economy.", Journal of World Business, Vol. 45 No. 3, pp. 257-265.

Manolova, T.S., Manev, I.M. and Gyoshev, B.S. (2014), "Friends with money? Owner's financial network and new venture internationalization in a transition economy.", International Small Business Journal, Vol. 32 No. 8, pp. 944-966.

Masso, J. and Vahter, P. (2014), "The Role of Product-Level Dynamics in Export Growth and Productivity: Evidence from Estonia.”, Emerging Markets Finance \& Trade, Vol. 50 
No. 4, pp. 42-60.

Melin, L. (1992), “Internationalization as a Strategy Process”, Strategic Management Journal, Vol. 13 No. S2, pp. 99-118.

Melitz, M.J. (2003), “The impact of trade on intra-industry reallocations and aggregate industry productivity”, Econometrica, Vol. 71 No. 6, pp. 1695-1725.

Meyer, K.E. and Gelbuda, M. (2006), "Process perspectives in international business research in CEE", Management International Review, Vol. 46 No. 2, pp. 143-164.

Michalski, B. (2014), "Competitiveness of Polish mid-tech and high-tech exports to the European Union (EU-27) in the first decade of the 21 st century.”, Poznan University of Economics Review, Vol. 14 No. 4, pp. 54-70.

Musteen, M., Datta, D.K. and Butts, M.M. (2014), “Do International Networks and Foreign Market Knowledge Facilitate SME Internationalization? Evidence From the Czech Republic.", Entrepreneurship: Theory \& Practice, Vol. 38 No. 4, pp. 749-774.

Musteen, M., Datta, D.K. and Francis, J. (2014), "Early Internationalization by Firms in Transition Economies into Developed Markets: The Role of International Networks.”, Global Strategy Journal, Vol. 4 No. 3, pp. 221-237.

Musteen, M., Francis, J. and Datta, D.K. (2010), "The influence of international networks on internationalization speed and performance: A study of Czech SMEs.”, Journal of World Business, Vol. 45 No. 3, pp. 197-205.

Mysen, T. (2013), “Towards a framework for controls as determinants of export performance: A review and analysis of empirical literature 1995-2011", European Business Review, Vol. 25 No. 3, pp. 224-242.

Nowiński, W. and Rialp, A. (2013), "Drivers and strategies of international new ventures from a Central European transition economy.", Journal for East European Management Studies, Vol. 18 No. 2, pp. 191-231.

OECD. (2015), "Glossary of Statistical Terms", available at: https://stats.oecd.org/glossary/detail.asp?ID=303 (accessed 20 September 2015).

Oviatt, B.M. and McDougall, P.P. (1994), "Toward a Theory of International New ventures", Journal of International Business Studies, Vol. 25 No. 1, pp. 45-64. 
Pittaway, L. and Cope, J. (2007), "Entrepreneurship education a systematic review of the evidence”, International Small Business Journal, Vol. 25 No. 5, pp. 479-510.

Radlo, M.-J. and Sass, M. (2012), "Outward Foreign Direct Investments and Emerging Multinational Companies from Central and Eastern Europe.”, Eastern European Economics, Vol. 50 No. 2, pp. 5-21.

Ramamurti, R. (2012), "What is really different about emerging market multinationals?", Global Strategy Journal, Vol. 2 No. 1, pp. 41-47.

Ratten, V., Dana, L.P., Han, M. and Welpe, I. (2007), “Internationalisation of SMEs: European comparative studies", International Journal of Entrepreneurship and Small Business, Vol. 4 No. 3, pp. 361-379.

Rumelt, R.P., Schendel, D.E. and Teece, D.J. (1994), Fundamental Issues in Strategy: A Research Agenda, Harvard Business School Press, Boston, MA.

Ruzzier, M. and Ruzzier, M.K. (2015), "On the relationship between firm size, resources, age at entry and internationalization: the case of Slovenian SMEs.", Journal of Business Economics \& Management, Vol. 16 No. 1, pp. 52-73.

Sass, M. (2012), "Internationalisation of innovative SMEs in the Hungarian medical precision instruments industry.", Post-Communist Economies, Vol. 24 No. 3, pp. 365-382.

Śliwiński, R. (2012), "Internationalization strategies of Polish fast growing enterprises.", Poznan University of Economics Review, Vol. 12 No. 1, pp. 17-39.

Smallbone, D. and Welter, F. (2006), "Conceptualising entrepreneurship in a transition context”, International Journal of Entrepreneurship and Small Business, Vol. 3 No. 2, pp. 190-206.

Söderqvist, A. and Kamala Chetty, S. (2013), "Strength of ties involved in international new ventures", European Business Review, Vol. 25 No. 6, pp. 536-552.

Stare, M. (2002), "The Pattern of Internationalisation of Services in Central European Countries.”, Service Industries Journal, Vol. 22 No. 1, pp. 77-91.

Svetličič, M., Jacklič, A. and Burger, A. (2007), "Internationalization of Small and MediumSize Enterprises from Selected Central European Economies.", Eastern European Economics, Vol. 45 No. 4, pp. 36-65. 
Thorpe, R., Holt, R., Macpherson, A. and Pittaway, L. (2005), “Using knowledge within small and medium-sized firms: A systematic review of the evidence", International Journal of Management Reviews, Vol. 7 No. 4, pp. 257-281.

Tranfield, D., Denyer, D. and Smart, P. (2003), “Towards a methodology for developing evidence-informed management knowledge by means of systematic review", British Journal of Management, Vol. 14 No. 3, pp. 207-222.

Vissak, T. and Masso, J. (2015), "Export patterns: Typology development and application to Estonian data.”, International Business Review, Vol. 24 No. 4, pp. 652-664.

Welch, L.S. and Luostarinen, R. (1998), “Internationalization: evolution of a concept”, Journal of General Management, Vol. 14 No. 2, pp. 34-55.

Wilinski, W. (2012), "Internationalisation through the Warsaw Stock Exchange: an empirical analysis.", Post-Communist Economies, Vol. 24 No. 1, pp. 145-154.

World Economic Forum. (2014), The Global Competitiveness Report 2014-2015, Geneve, Switzerland.

Wright, M., Filatotchev, I., Hoskisson, R.E. and Peng, M.W. (2005), "Strategy research in emerging economies: Challenging the conventional wisdom", Journal of Management Studies, Vol. 42 No. 1, pp. 1-33.

Wright, R.W. and Dana, L.-P. (2003), “Changing Paradigms of International Entrepreneurship Strategy", Journal of International Entrepreneurship, Vol. 1 No. 1, pp. 135-152.

Yamakawa, Y., Peng, M.W. and Deeds, D.L. (2008), "What drives new ventures to internationalize from emerging to developed economies?", Entrepreneurship: Theory and Practice, Vol. 32 No. 1, pp. 59-82.

Zapletalová, Š. (2015), “Models of Czech companies' internationalization.”, Journal of International Entrepreneurship, Vol. 13 No. 2, pp. 153-168. 
Table 1 - Search protocol and results

\begin{tabular}{lll}
\hline Step & Description & $\begin{array}{l}\text { Total } \\
\text { articles }\end{array}$ \\
\hline 0 & Articles retrieved from EBSCO & 907 \\
1 & Articles whose title was relevant & 96 \\
2 & $\begin{array}{l}\text { Articles whose abstract was } \\
\text { relevant }\end{array}$ & 45 \\
3 & Articles whose text was relevant & 30 \\
\hline
\end{tabular}

Source: Our dataset

Table 2 - Clusters' distribution

International International International

\begin{tabular}{l|l|l|l|}
\multicolumn{1}{c}{} & \multicolumn{1}{c}{ Processes } & Variables & \multicolumn{1}{c}{ Outcomes } \\
\cline { 2 - 4 } Generic & 5 & 3 & 2 \\
\cline { 2 - 4 } $\begin{array}{l}\text { Export } \\
\text { Network }\end{array}$ & 7 & 8 & 7 \\
\cline { 2 - 4 } OFDI & 6 & 4 & 3 \\
\cline { 2 - 4 } & & 0 & 0
\end{tabular}

Source: Our dataset 
Table 3-Articles' distribution per journal

\begin{tabular}{|c|c|c|c|c|}
\hline Journal & Articles & SCImago H-Index & SCImago SJR & JCR Impact Factor \\
\hline Poznan University of Economics Review & 3 & - & - & - \\
\hline Eastern European Economics & 2 & 13 & 0.285 & 0.302 \\
\hline Emerging Markets Finance \& Trade & 2 & 17 & 0.35 & - \\
\hline International Business Review & 2 & 57 & 1.166 & 1.713 \\
\hline Journal for East European Management Studies & 2 & 7 & 0.259 & - \\
\hline Journal of Economics \& Management & 2 & - & - & - \\
\hline Journal of World Business & 2 & 60 & 1.709 & 2.388 \\
\hline Post-Communist Economies & 2 & 16 & 0.337 & 0.492 \\
\hline Academy of Management Journal & 1 & 205 & 9.398 & 6.448 \\
\hline Entrepreneurship \& Regional Development & 1 & 49 & 1.29 & 1.519 \\
\hline Entrepreneurship: Theory \& Practice & 1 & 68 & 2.811 & 3.144 \\
\hline Finance a Uver: Czech Journal of Economics \& Finance & 1 & - & - & - \\
\hline Global Strategy Journal & 1 & - & - & 3.694 \\
\hline International Small Business Journal & 1 & 40 & 1.444 & 1.800 \\
\hline Journal of Business Economics \& Management & 1 & 21 & 0.411 & 0.723 \\
\hline Journal of Developmental Entrepreneurship & 1 & 11 & 0.33 & - \\
\hline Journal of International Entrepreneurship & 1 & 18 & 0.739 & - \\
\hline Journal of International Food \& Agribusiness Marketing & 1 & 13 & 0.207 & - \\
\hline Journal of Management \& Governance & 1 & 30 & 0.568 & - \\
\hline Service Industries Journal & 1 & 38 & 0.471 & 0.832 \\
\hline World Economy & 1 & 43 & 0.631 & 0.727 \\
\hline Total & 30 & & & \\
\hline
\end{tabular}

Sources: Our dataset, SCImago Journal Rank (2014) and JCR Impact Factor (2014)

Table 4 - Articles' distribution per journal

\begin{tabular}{lll}
\hline $\mathrm{n}$ & Journal & Articles \\
\hline 1 & Poland & 17 \\
2 & Czech Republic & 7 \\
3 & Estonia & 5 \\
4 & Hungary & 5 \\
5 & Slovenia & 4 \\
6 & Bulgaria & 2 \\
7 & Slovakia & 2 \\
8 & Latvia & 1 \\
9 & Lithuania & 1 \\
10 & Romania & 1 \\
Total & & 45 \\
\hline
\end{tabular}

Source: Our dataset 
Table 5 - Clusters' distribution

\begin{tabular}{|c|c|c|}
\hline International Processes & International Variables & International Outcomes \\
\hline $\begin{array}{l}\text { Hitt, Dacin, Levitas, Arregle \& } \\
\text { Borza (2000); Stare (2002); } \\
\text { Svetličič, Jacklič \& Burger (2007); } \\
\text { Malo \& Norus (2009); Blanke- } \\
\text { Ławniczak (2009); Cieslik \& } \\
\text { Kaciak (2009); Musteen, Francis \& } \\
\text { Datta (2010); Fonfara } \\
\text { (2011); Sass (2012); } \\
\text { Wilinski (2012); Śliwiński (2012); } \\
\text { Radlo \& Sass (2012); Jarosiński } \\
\text { (2013); Nowiński \& Rialp (2013); } \\
\text { Gorynia, Nowak, Trąpczyński \& } \\
\text { Wolniak (2013); Masso \& Vahter } \\
\text { (2014); Cieślik, } \\
\text { Michałek, Michałek \& Mycielski } \\
\text { (2015); Vissak \& Masso (2015); } \\
\text { Zapletalová (2015); Gorynia, } \\
\text { Nowak, Trąpczyński \& Wolniak } \\
\text { (2015) }\end{array}$ & $\begin{array}{l}\text { Filatotchev, Isachenkova \& } \\
\text { Mickiewicz (2007); Manolova, } \\
\text { Manev \& Gyoshev (2010); } \\
\text { Musteen, Francis \& Datta (2010); } \\
\text { Hagemejer \& Kolasa (2011); } \\
\text { Hobdari, Gregoric \& Sinani (2011); } \\
\text { Nowiński \& Rialp (2013); } \\
\text { Michalski (2014); Musteen, Datta } \\
\text { \& Butts (2014); Musteen, Datta \& } \\
\text { Francis (2014); Manolova, Manev } \\
\text { \& Gyoshev (2014); Cieślik, } \\
\text { Kaciak \& Thongpapanl (2015); } \\
\text { Vissak \& Masso (2015) }\end{array}$ & $\begin{array}{l}\text { Filatotchev, Isachenkova \& } \\
\text { Mickiewicz (2007); Malo \& Norus } \\
\text { (2009); Fonfara (2011); Hagemejer } \\
\text { \& Kolasa (2011); Michalski (2014); } \\
\text { Musteen, Datta \& Butts (2014); } \\
\text { Masso \& Vahter (2014); Cieślik, } \\
\text { Michałek, Michałek \& Mycielski } \\
\text { (2015); Ruzzier \& Ruzzier (2015); } \\
\text { Vissak \& Masso (2015) }\end{array}$ \\
\hline $\mathrm{N}=20$ & $\mathrm{~N}=12$ & $\mathrm{~N}=10$ \\
\hline
\end{tabular}

Source: Our dataset 
Figure 1: Articles' distribution over time (Source: Our dataset)

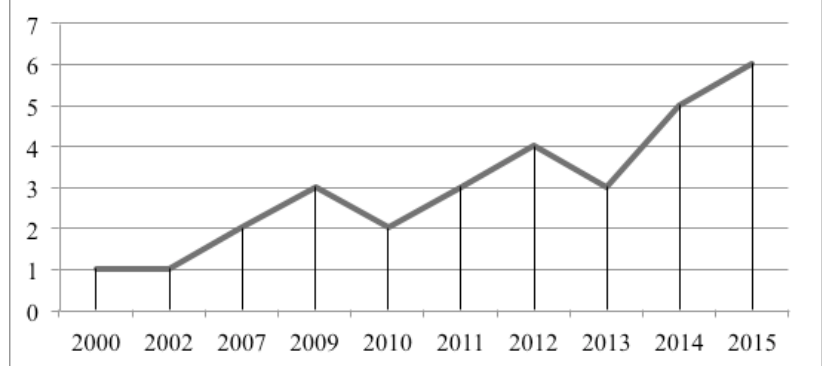

Figure 2: Clusters' distribution over the time period (Source: our dataset)

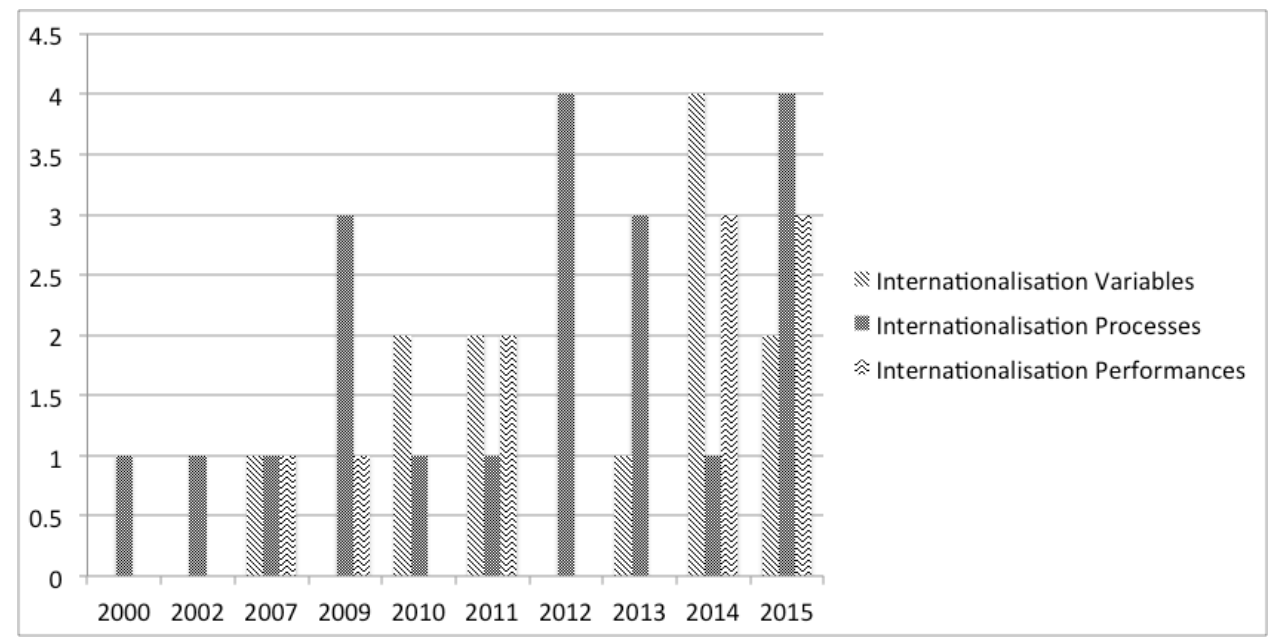

